\title{
Implant impression using closed mouth impression technique: a case report
}

\author{
So-Yeun Kim,4, Joo-Hyeun Kim², Kyoung-Hwa Jung, ${ }^{1}$, Hye-Mi Jeon', Eun-Sook Kang³ , Mi-Jung Yun ${ }^{4 *}$ \\ 'Dental Clinic Center, Pusan National University Hosptial, Busan, Republic of Korea \\ ${ }^{2}$ Nanum E Dental clinic, Suwon, Repubilc of Korea \\ ${ }^{3}$ Department of Prosthodontics, In-Je University Haeundae Paik Hospital, Busan, Republic of Korea \\ ${ }^{4}$ Department of Prosthodontics, School of Dentistry, Pusan National University, Yangsan, Republic of Korea
}

Closed mouth impression technique by using bite tray is preferred for single tooth impression taking. However, for implant impression taking, open mouth impression technique by using single arch tray is generally used whether it is for single implant or multiple implant. Closed mouth impression technique by using bite tray can save time and materials. It also decreases the chance of error occurrence when a model is mounted on an articulator. In this case report, we tried to show a satisfying result of fabricating single implant fixed prosthodontics after bite tray impression taking by using two different copings for closed mouth impression. (J Dent Rehabil Appl Sci 2017;33(3):223-9)

Key words: closed mouth impression technique; impression implant; bite tray

\section{서론}

일반적으로 단일 치아의 보철 제작을 위한 인상채득 은 바이트 트레이를 이용한 인상채득으로서 이는 한 번 에 상하악의 관계와 지대치의 인상을 동시에 채득하는 방법이다. ${ }^{1}$ 바이트 트레이를 이용하는 폐구인상법은 시 간이 절약되고 재료가 적게 들며 환자가 편하다는 장점 이 있다. ${ }^{2}$ 한편 임플란트 보철을 위한 인상채득의 경우, 단일치와 다수치의 구분 없이 주로 pick up 인상법 또는 transfer 인상법으로 구분되어 있고 주로 상하악을 따로 개구인상채득 후 교합기에 부착하였다. ${ }^{3}$ 동요도가 거의 없는 임플란트의 특성상 임상, 기공 과정에서의 오차를 수용하기가 더 어렵기 때문에 정확한 작업모형을 얻기 위한 인상 과정은 중시된다. ${ }^{4,5}$ 특히 pick up 인상법은 교 합면에 수직한 방향에서 transfer 인상법보다 좀더 정확

*Correspondence to: Mi-Jung Yun

Professor, Department of Prosthodontics, School of Dentistry, Pusan National University, 49, Busandaehak-ro, Mulgeum-eup, Yangsan, 50612, Republic of Korea Tel: +82-55-360-5134, Fax: +82-55-360-5130, E-mail: p-venus79@hanmail.net Received: July 19, 2017/Last Revision: August 19, 2017/Accepted: August 21, 2017
한 인상으로 평가되어 주로 사용되고 있다.

그러나 개구인상법으로 전악 인상을 채득하여 교합기 에 부착한 모형의 경우 각 모형 내 임플란트 위치의 정확 성은 확보할 수 있더라도 교합기 부착 단계에서 기포 등 하나의 오류가 전체 교합관계에 영향을 미칠 수 있으며 이런 경우 폐구인상법으로 인상채득 후 교합기에 부착 한 모형에 비해 큰 교합 오차가 발생한다. 그러므로 악 간 공간이 충분하고 대합되는 치아가 충분하여 상하악 간 교합 수직고경이 유지되고 있는 단일 임플란트 인상 채득의 경우에는 바이트 트레이를 이용한 폐구인상이 오 차 발생에 대해 유리할 수 있다. 바이트 트레이를 이용한 폐구인상채득 시에는 임플란트와 치아의 인상이 교합력 하에서 동시에 이루어질 수 있고, 동일한 교두 위치가 재 현될 수 있으므로 구강 상태를 정확하게 복제할 수 있다. 또한, 상하악 악간 위치 관계가 더 정확하며, 인상채득 부

Copyright $@ 2017$ The Korean Academy of Stomatognathic Function and Occlusion. (c) It is identical to Creative Commons Non-Commercial License. 
위가 최소화되는 유리한 점이 있다. ${ }^{8}$

폐구인상채득을 위해서는 인상 방법 상 transfer 인상 용 코핑 형태가 필요하다. 인상용 코핑은 표면, 길이 등 디자인에 따라 인상의 정확도에 영향을 미치게 되며 아 크릴릭 레진 transfer cap이 있는 등 특별한 형태를 갖는 인상용 코핑은 좀 더 정확한 인상을 얻는다고 보고되었 다. ${ }^{9}$ 기존의 transfer 인상용 코핑은 코핑의 안정성을 얻기 위해 길이가 인접치보다 길게 제작되어 대합치와의 공간 을 고려하지 않는 개구인상법을 전제로 제작되었다.

임플란트 치료가 일반화되었으나 정밀하면서 동시에 간편한 인상채득 방법이 널리 확산되지는 않았다. 본 증 례보고에서는 2 가지 종류의 폐구인상용 코핑을 이용해 바이트 트레이로 인상채득 후 단일 임플란트 고정성 보 철물을 제작함에 있어 만족할 만한 결과를 얻어 보고하 고자 한다.

\section{증례보고}

\section{증례 1}

48세 남환으로 8 년 전에 식립한 상악 좌측 제 2 소구치 임플란트 고정체의 동요도를 주소로 내원하였다. 엑스 레이 촬영 결과 고정체의 파절이 관찰되어 발거하고 4개 월 뒤 폭 $4.5 \mathrm{~mm}$, 길이 $10 \mathrm{~mm}$ 의 임플란트 고정체(TSIII $\mathrm{SA}$, Osstem, Seoul, Korea)를 one-step 방식으로 식립 하였다. 치유 기간 후 ISQ 75의 안정된 골융합을 확인하 여 보철 치료를 시작하였다. 체결된 치유 지대주를 기준 으로 비교해 보았을 때 임플란트 플랫폼에서 교합면까지 거리가 바이트 인상용 코핑의 길이인 $8 \mathrm{~mm}$ 보다 길며 식
립 방향이 인접치 치축과 비슷하여 바이트 인상용 코핑 시스템(AD-I-ONE, ROADDENTAL, Incheon, Korea) 을 이용하여 바이트 트레이 인상채득을 하기로 하였다 (Fig. 1).

식립된 임플란트 고정체의 규격에 맞는 폭 $4.5 \mathrm{~mm}$, cuff 높이 $4 \mathrm{~mm}$ 의 코핑(AD abutment, ROADDEN$\mathrm{TAL})$ 을 선택 후 코핑의 상부에 폭 $4.5 \mathrm{~mm}$ 의 인상용 cap (AD impression cap, ROADDENTAL)을 체결하였다. 코핑의 상부에 인상용 cap을 체결 시 하나의 둥근 nutch 및 두 개의 일직선 nutch가 각각의 위치에 일치하도록 위 치시켰다. 인상용 cap이 결합된 코핑이 임플란트 고정체 에 연결될 때 임플란트 플랫폼 상부로 노출되는 길이는 $8 \mathrm{~mm}$ 이므로 인상채득 시 $8 \mathrm{~mm}$ 이상의 공간이 필요하 다(Fig. 2). 인상용 cap이 결합된 코핑을 구강 내 임플란

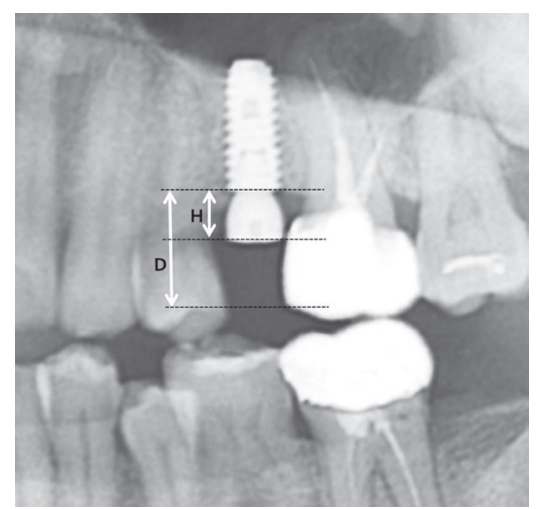

Fig. 1. Measurements performed on radiograph. $\mathrm{H}$ is $4 \mathrm{~mm}$. Based on the radiographic view, $D$ is supposed to be more than two times of $\mathrm{H}$. $\mathrm{H}$, height of healing abutment; $D$, distance from the fixture platform to the expected occlusal surface.
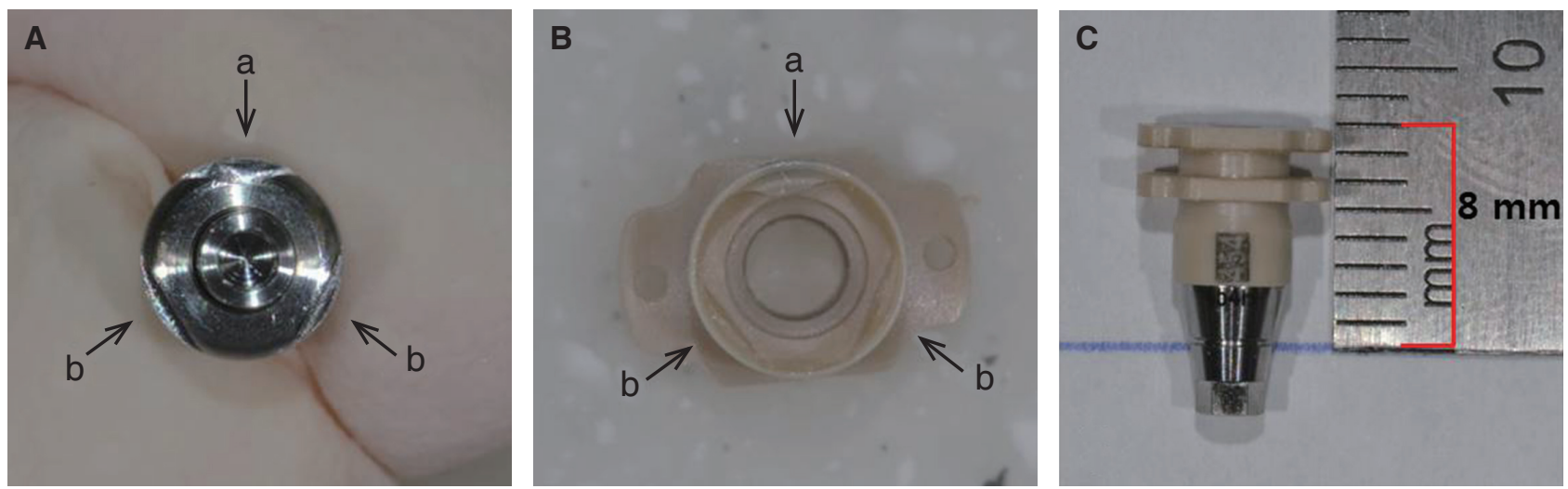

Fig. 2. (A) Impression coping, (B) Impression cap, (C) Impression coping with impression cap. The total length above the fixture platform is $8 \mathrm{~mm}$. a, round nutch; $b$, flat nutch. 

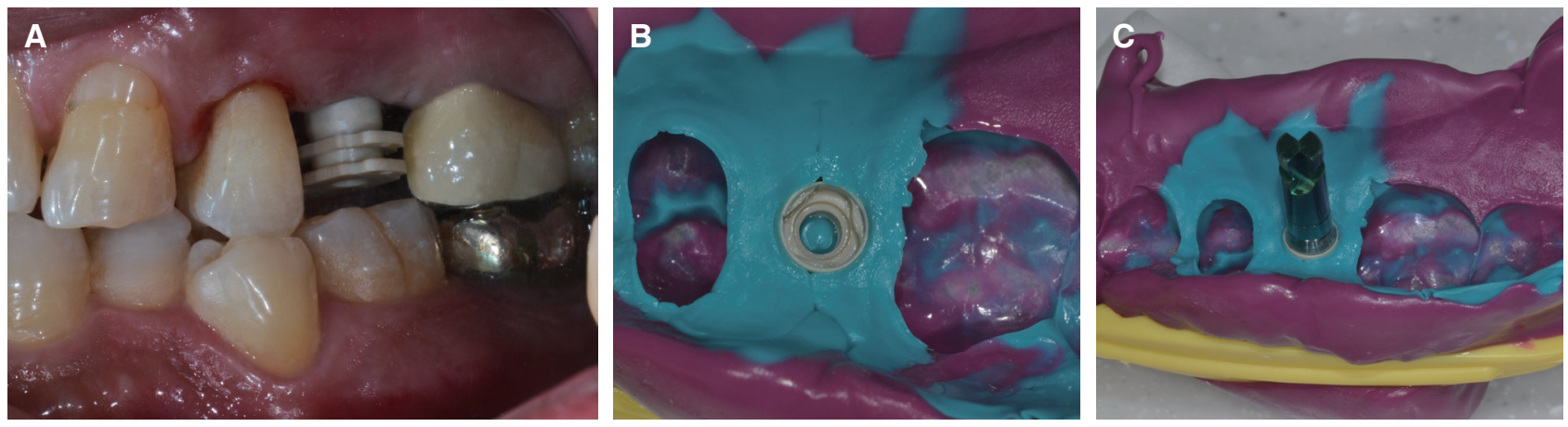

Fig. 3. (A) Impression coping with cap is connected to the implant fixture. (B) Impression cap was removed from the mouth together with the set impression while impression coping was retained in the mouth. (C) Reposition the impression coping connected with the laboratory analog in the impression cap.
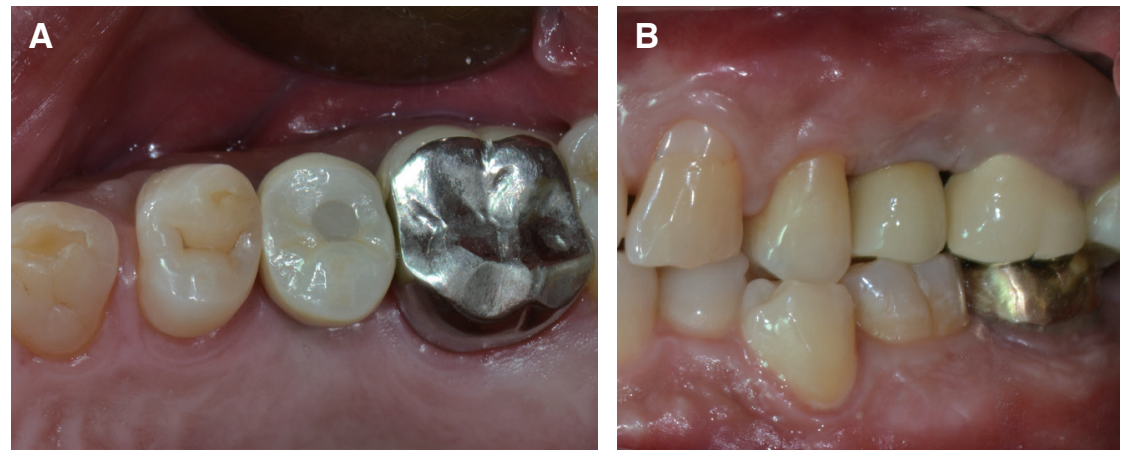

Fig. 4. Six months after definitive prosthesis delivery. (A) Occlusal view. (B) Lateral view.

트 고정체에 연결하고 Acu-Film 교합지를 이용하여 대 합치와 간섭이 없는 것을 확인 후 구치부용 바이트 트레 이(Dentian bite tray, Seilglobal, Busan, Korea)와 실리콘 인상재(Aquasil Ultra Monophase and Aquasil Ultra LV, Dentsply DeTrey GmbH, Konstanz, Germany)를 이용 하여 상악 좌측 제 2 소구치 임플란트를 위한 인상채득을 하였다. 이후 구강 내에 남아 있는 인상용 코핑을 제거하 여 임프란트 유사체와 연결 후 인상체 내에 남아있는 인 상용 cap에 재위치 시켰다(Fig. 3).

Type IV 석고(SnowRock, DK Munkyo, Gimhae, Ko$\mathrm{rea}$ 를 $100 \mathrm{~g}$ 당 물 $20 \mathrm{~mL}$ 의 혼수비로 진공 혼합하여 인 상체에 주입하고 초기 경화 후 대합치 부분에 Type III 석고(SnowRock, DK Munkyo)를 부었다. 1시간 후 인상 체에서 모형을 제거하고 모형을 트리밍 후 단순 접번 교 합기에 교합기 장착하였다. 이상적인 emergence profile 형성 및 최종 보철물의 균일한 두께를 확보하기 위하여 맞춤형 지대주를 제작하였으며 상부에 나사 구멍을 형성 한 완전 지르코니아 보철물을 제작하였다.

보철물 장착 날, 구강 내에서 치유 지대주 제거 및 맞
춤 지대주 체결 후, 상부에 크라운을 시적하여 변연 적 합, 인접면 접촉 및 대합치와 교합 상태를 확인하고 평가 하였다. $30 \mathrm{Ncm}$ 토크로 나사를 조인 후 10 분 뒤 다시 조 임 토크 부여 ${ }^{10}$ 후 지르코니아 크라운을 레진 시멘트(RelyX ${ }^{\mathrm{TM}} \mathrm{U} 200,3 \mathrm{M}$ ESPE, Seefeld, Germany)로 접착하고 정기적인 유지관리 시행하였다(Fig. 4).

\section{증례 2}

62세 여환으로 상악 좌측 제1대구치 치관이 우식으로 상실되고 치근만 남아 이 치아를 발거 후 임플란트를 식 립하기 위해서 내원하였다. 상악 좌측 제 1 대구치 치근을 발거하고 3개월 뒤, 폭 $4.5 \mathrm{~mm}$, 길이 $8.5 \mathrm{~mm}$ 의 임플란 트 고정체(TSIII SA, Osstem)를 one-step 방식으로 식립 하였다. 4 개월 뒤 악간 거리가 충분하고 임플란트 고정체 의 식립 방향이 인접치 치축과 비슷하여 증례 1 과 기능이 비슷한 또 다른 회사의 바이트 인상용 코핑 시스템(Bite Impression Coping, SHINHUNG, Seoul, Korea)을 이 용하여 바이트 트레이로 폐구인상채득 하였다. 

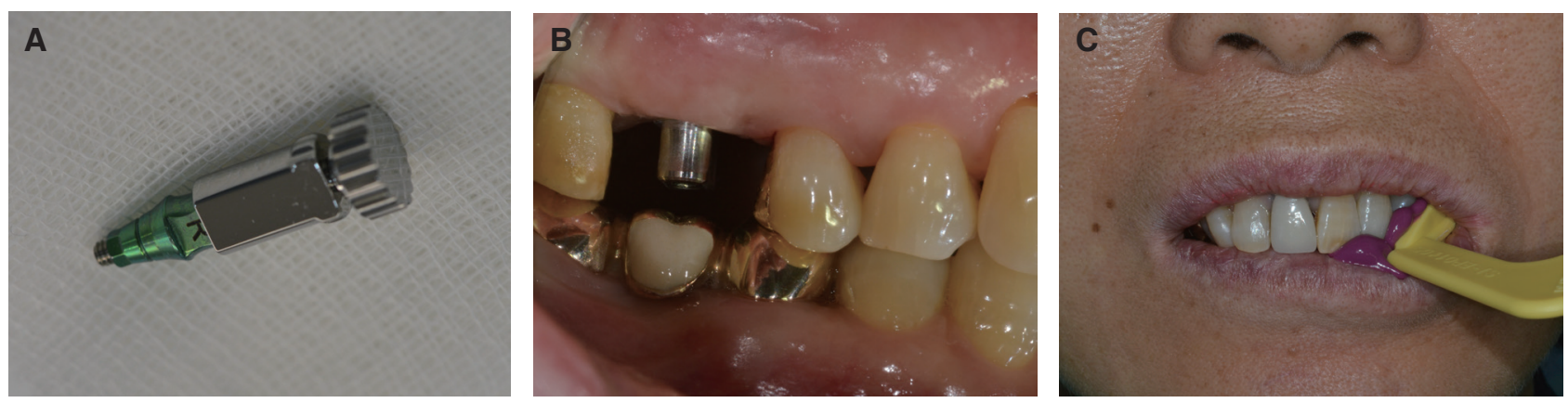

Fig. 5. (A) Impression coping connected with bite impression coping driver. (B) Intraoral view of impression coping in place. (C) The patient is biting the bite tray according to the conventional impression taking method.
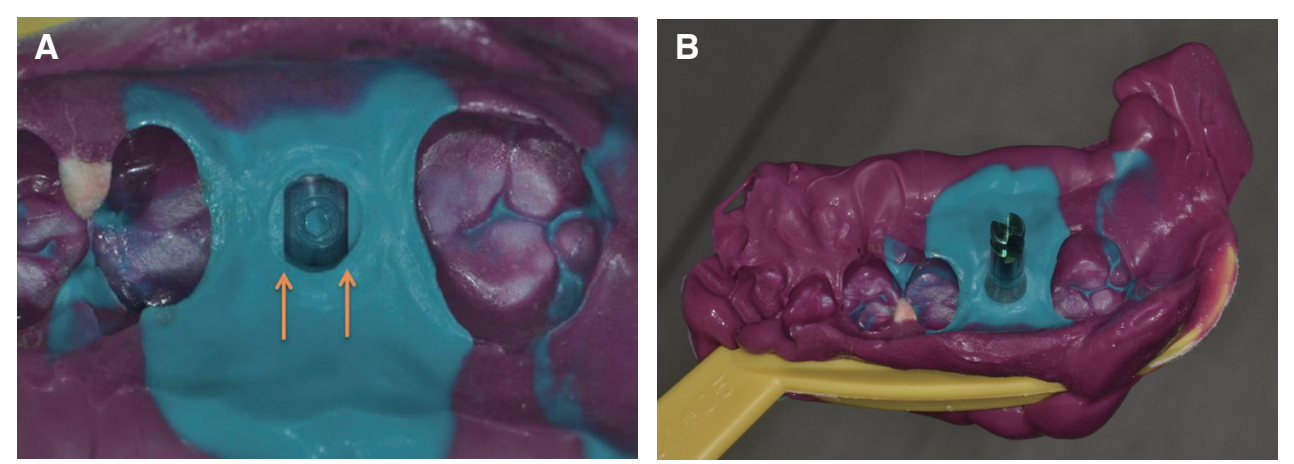

Fig. 6. (A) Impression body was removed from the oral cavity while impression coping remained in the mouth. The shape of the coping in the impression shows parallel two faces (arrows) facing each other. (B) The impression copings removed from the mouth were repositioned on the impression after connecting with the laboratory analog.
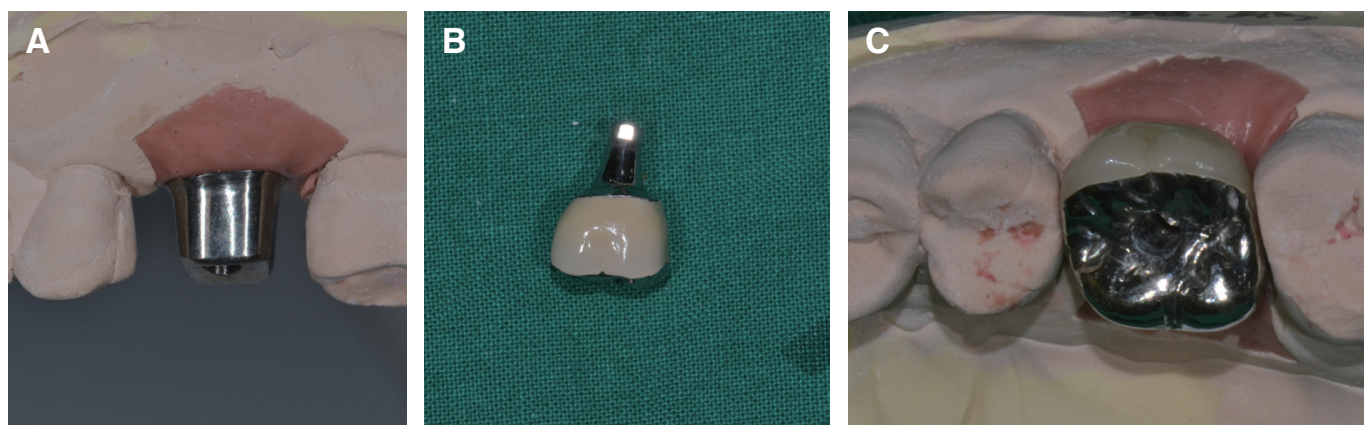

Fig. 7. (A) Customized abutment on working cast. (B) Customized abutment and PFM crown. (C) Restoration on the definitive model.

상부 길이 $4 \mathrm{~mm}$, 치은 높이 $4 \mathrm{~mm}$ 의 인상용 코핑 (Luna, Bite Impression Coping, SHINHUNG)을 선택 후 전용 드라이버(Bite Impression Coping Driver, SHINHUNG)로 임플란트 고정체에 체결하였다. 인상용 코 핑의 크기가 작고 잡을 수 있는 형태가 없으나 전용 드라 이버를 연결하였을 때 술자가 잡을 수 있는 길이와 형태 가 되어 고정체에 코핑을 연결하는 과정에서 코핑의 위치 고정에 유리하였다. 인상용 코핑과 대합치가 서로 간섭 이 없는 것을 확인 후 구치부용 바이트 트레이와 실리콘 인상재를 이용하여 인상채득을 하였다(Fig. 5).
구강 내에서 인상용 코핑을 제거하여 임플란트 유사체 와 연결하였다. 인상체에 채득된 인상용 코핑 형상에서 평행한 두 면에 맞추어 임플란트 유사체가 연결된 코핑 을 조심스럽게 끼워 넣었다(Fig. 6). 위치된 임플란트 유사 체 경부 주변으로 artificial gum 제작용 인상재를 주입한 뒤 초경석고 주입 하고 반대편에 경석고 주입하여 바이트 트레이에서 모형을 완성 후 교합기 장착하였다. 이상적인 emergence profile 형성 및 최종 보철물의 균일한 두께를 보장하기 위하여 맞춤형 지대주를 제작 후 상부에 나사 구멍을 형성한 금속 도재 보철물을 제작하였다(Fig. 7). 

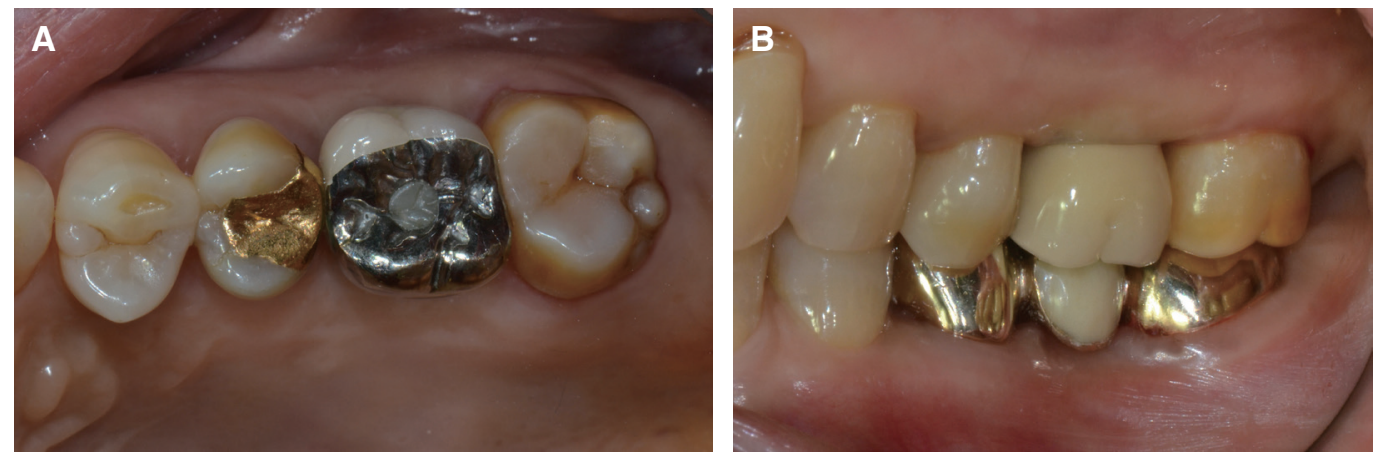

Fig. 8. Five months after definitive prosthesis delivery. (A) Occlusal view. (B) Lateral view.

구강 내에서 치유 지대주 제거 및 맞춤형 지대주 체결 후, 상부에 크라운을 시적하여 변연 적합, 인접면 접촉 및 대합치와 교합 상태를 확인하고 평가하였다. $30 \mathrm{Ncm}$ 토 크로 나사를 조인 후 10 분 뒤 다시 조임 토크 부여 후 금 속 도재관을 레진 시멘트(RelyX ${ }^{\mathrm{TM}} \mathrm{U} 200,3 \mathrm{M}$ ESPE)로 접착하고 정기 점검하였다(Fig. 8).

\section{고찰}

임플란트는 자연치와 달리 동요도가 거의 없기 때문에 정밀한 인상채득을 통해 임플란트 고정체와 상부 보철물 간 수동적 적합을 얻는 것이 중요하다. ${ }^{11}$ 그동안 임플란 트 인상채득을 위해서는 중합 후 변형이 적은 실리콘 인 상재와 개인 트레이를 이용한 개구인상채득법을 시행하 였다. 대표적으로 임플란트 개구인상채득법은 transfer 인상법 및 pick up 인상법 두 가지로 구별되고 회사 별로 약간의 모양의 차이는 있지만 편악 트레이를 이용하는 점은 동일하였다. ${ }^{12}$

그러나 최근, 재료의 낭비, 부가적 환자의 내원 횟수, 치료 기간, 비용 등을 줄이기 위한 기능과 목적을 가진 제품들이 꾸준히 개발되고 있고 앞서 두 증례에 사용된 AD-I-ONE과 바이트 인상 코핑의 경우, 바이트 트레이 를 이용한 폐구인상법을 통해 이를 도모하였다. ${ }^{13}$ 폐구 인상채득은 한 번의 인상채득으로 대합치와 대합치와의 관계를 같이 채득할 수 있어 따로 바이트 인기를 할 경우 생길 수 있는 오차를 줄일 수 있다. ${ }^{14}$ 그러므로 많은 정보 가 필요 없는 짧은 인상채득 범위에서는 바이트 트레이 를 이용한 폐구인상채득이 필요한 정보만 얻어내고 절차 를 줄일 수 있어 유리한 효과를 나타낼 것이라 기대할 수 있다.

기존 transfer type 인상용 코핑과 최근 폐구인상채득
을 고려한 코핑은 인상체에서 코핑이 분리되었다가 재위 치 된다는 원리가 같다. 그러나 transfer type 인상용 코핑 의 경우, 개구인상법을 전제로 제작되었기 때문에 긴 형 태를 가짐으로써 접촉 면적을 넓혀 인상체 내로 고정되 도록 디자인된 반면 폐구인상채득용 코핑의 경우 좁은 악간 공간에 적용 가능한 길이를 가지고 있고, 상대적으 로 짧은 코핑을 인상체 내로 정확한 위치로 고정시키기 위해 형태적 요소가 부여되었다.

첫 번째 증례의 경우 인상체 내로 인상용 코핑을 재위 치 시키기 위한 인상용 cap이 따로 있어 인상체 내에 코핑 을 넣었을 때 단단히 잡아 주는 장점이 있었지만 그만큼 구강 내에서 요구 공간이 길어져 최소 $8 \mathrm{~mm}$ 의 공간이 있 는 증례가 아닌 경우 사용하기가 어려웠다. 두 번째 증례 의 경우 인상용 코핑만 연결하면 되어 악간 공간이 더 짧 은 곳에서 사용 가능하였으나 인상체 내에 임플란트 유 사체를 연결한 코핑을 단지 $4 \mathrm{~mm}$ 깊이의 중합된 실리콘 인상재로 고정하므로 상대적으로 불안정하였다. 그러나 두 증례 모두 임상적 결과는 큰 차이가 없었다.

인상채득 과정에서 트레이 변형은 이후 인상체의 변형 을 야기할 수 있기 때문에 바이트 트레이 재료는 견고성 이 있어 채득 과정에서 변형이 일어나지 않는 재료를 사 용하는 것이 바람직하다. ${ }^{1}$ 그러나 경화 후 단단해진 실 리콘 인상재가 트레이의 변형 후 반동을 막는 역할을 한 다. ${ }^{7}$ 단일 임플란트를 인상채득한 본 증례에서는 플라스 틱 바이트 트레이를 사용하고 흐름성이 좋은 light body 와 medium body 실리콘 인상재를 사용하였으나 임상적 으로 만족할 만한 결과를 나타냈다.

두 증례 모두 최후방 구치부가 있는 단일 치아를 인상 채득 하는 단순한 증례였다. 그러나 최후방 구치부를 포 함한 다수 치아의 인상채득을 하는 경우나 교합 형식을 결정해야 하는 경우 등이 아닌 경우에는 바이트 트레이 
를 이용한 임플란트 인상채득이 시도 가능하다고 생각 된다. 플라스틱 바이트 트레이가 아닌 금속 프레임을 가 진 바이트 트레이의 사용, light body 가 아닌 heavy body 등의 경화 후 더 견고한 인상재의 사용 등으로 이와 같은 폐구인상 적용 범위를 넓힐 수 있을 것으로 사료된다.

\section{결론}

바이트 인상 코핑 을 이용한 임플란트 단일 고정성 보 철물 인상채득에서 임상적으로 만족할 만한 결과를 보 여주었다. 이러한 방법을 통해 환자 내원 횟수 및 chair time 이 줄어들었으며 술자와 환자 모두 만족한 결과를 얻을 수 있었다.

\section{Acknowledgements}

본 연구는 2017년도 부산대학교병원 임상연구비 지원 으로 이루어졌음.

\section{ORCID}

So-Yeun Kim https://orcid.org/0000-0002-3043-2723

Joo-Hyeun Kim https://orcid.org/0000-0003-2281-6978

Kyoung-Hwa Jung https://orcid.org/0000-0002-83050016

Hye-Mi Jeon https://orcid.org/0000-0003-0007-5662

Eun-Sook Kang https://orcid.org/0000-0002-4495-4135

Mi-Jung Yun https://orcid.org/0000-0003-3093-8406

\section{References}

1. de Lima LM, Borges GA, Junior LH, Spohr AM. In vivo study of the accuracy of dual-arch impressions. J Int Oral Health 2014;6:50-5.

2. Burke FJ, Crisp RJ. A practice-based assessment of the handling of a fast-setting polyvinyl siloxane impression material used with the dual-arch tray technique. Quintessence Int 2001;32:805-10.

3. Carr AB. Comparison of impression techniques for a five-implant mandibular model. Int J Oral Maxillofac Implants 1991;6:448-55.

4. Sekine H, Komiyama Y, Potta H, Yoshida K. Mobility characteristics and tactile sensitivity of os- seointegrated fixture-supporting systems. In: van Steenberghe D, Albrektsson T, Brånemark PI, Henry PJ, Holt R, Liden G, editors. Tissue integration in oral and maxillofacial reconstruction. Amsterdam; Excerpta Medica; 1986. p. 326-32.

5. Tautin FS. Impression making for osseointegrated dentures. J Prosthet Dent 1985;54:250-1.

6. Assif D, Fenton A, Zarb G, Schmitt A. Comparative accuracy of implant impression procedures. Int J Periodontics Restorative Dent 1992;12:112-21.

7. Parker MH, Cameron SM, Hughbanks JC, Reid DE. Comparison of occlusal contacts in maximum intercuspation for two impression techniques. J Prosthet Dent 1997;78:255-9.

8. Suzuki Y, Shimpo H, Ohkubo C, Kurtz KS. Fabrication of fixed implant prostheses using function bite impression technique (FBI technique). J Prosthodont Res 2012;56:293-6.

9. Liou AD, Nicholls JI, Yuodelis RA, Brudvik JS. Accuracy of replacing three tapered transfer impression copings in two elastomeric impression materials. Int J Prosthodont 1993;6:377-83.

10. Siamos G, Winkler S, Boberick KG. Relationship between implant preload and screw loosening on implant-supported prostheses. J Oral Implantol 2002;28:67-73.

11. Adell R, Lekholm U, Rockler B, Brånemark PI. A 15 -year study of osseointegrated implants in the treatment of the edentulous jaw. Int J Oral Surg 1981;10:387-416.

12. Chee W, Jivraj S. Impression techniques for implant dentistry. Br Dent J 2006;201:429-32.

13. Neobiotech. Pickcap Kit. Available from: http:// www.neobiotechus.com/index.php/others/pickcap-kit.html (updated 2017 July 11).

14. Ockert-Eriksson G, Eriksson A, Lockowandt P, Eriksson O. Materials for interocclusal records and their ability to reproduce a 3-dimensional jaw relationship. Int J Prosthodont 2000;13:152-8. 


\section{폐구인상채득법을 이용한 임플란트 인상채득 증례}

\section{김소연 ${ }^{1,4}$, 김주현 ${ }^{2}$, 정경화 ${ }^{1}$, 전혜미 ${ }^{1}$, 강은숙 ${ }^{3}$, 윤미정 ${ }^{4 *}$}

${ }^{1}$ 부산대학교병원 치과진료센터

${ }^{2}$ 나눔E치과의원

${ }^{3}$ 인제대학교 해운대백병원 치과보철과

${ }^{4}$ 부산대학교 치의학전문대학원 치과보철학교실

단일 치아의 인상채득을 위해서는 바이트 트레이를 이용한 폐구인상법이 선호된다. 그러나 임플란트 인상채득을 위해서 는 단일치와 다수치 구분 없이 편악 트레이를 이용한 개구인상법이 주로 사용되고 있다. 바이트 트레이를 이용하는 폐구 인상법은 시간이 절약되고 재료가 적게 들며, 모형의 교합기 부착 시 상하악 악간 위치 관계 오차 발생 확률이 적다. 본 증례에서는 2 가지 종류의 폐구인상용 코핑을 이용해 바이트 트레이로 인상채득 후 단일 임플란트 고정성 보철물을 제 작함에 있어 만족할 만한 결과를 얻어 보고하고자 한다.

(구강회복응용과학지 2017;33(3):223-9)

주요어: 폐구인상법; 임플란트 인상채득; 바이트 트레이 